\title{
Mathematic Learning Material Capabilities on Special Needs
}

\author{
Sri Wuryanti ${ }^{1}$, Fahmi ${ }^{1}$, Giri Sarana Hamiseno ${ }^{1}$ \\ ${ }^{1}$ Center for Assessment and Learning, Research and Development Agency, \\ Ministry of Education, Indonesia
}

\begin{abstract}
Study was all high school level students who took the National Examination for the 2018/2019 academic year, while the research sample was all-inclusive high school students who took the National Examination for the 2018/2019 academic year. The data used is secondary data, namely the High School National Exam data for the 2018/2019 academic year. Data analysis using Excel software, and then descriptive statistical analysis was carried out. The results showed the highest score of the National Mathematics Examination for students with special needs in inclusive schools was 54.02 and the lowest was 22.69 with an average score of 39.43. The average score of Mathematics for the Science Department is 45.66 (included in the poor category), the Language Department is 40.04 (including the poor category), while the Social Science Department is 29.28 (including the low category). The highest average absorption power of Mathematics in the Science department is $30 \%$, in the scope of Algebra material, the lowest absorption is $23 \%$ in the scope of calculus material. In the social studies department, the highest average absorption power in mathematics is $29 \%$ each for algebra and statistics, the lowest absorption rate is $18 \%$ in the scope of Geometry and Trigonometry. Meanwhile, in the Language Department, the highest average absorption is algebra 38\%, the lowest is 30\% in the scope of Geometry and Trigonometry. The range of values for participants with special needs is very large so it needs assistance to improve the abilities of students. The weakness of special needs students in Mathematics is the material scope of Geometry and Trigonometry.

Keywords: National Examination, Material Capabilities, Mathematic, Children with special needs
\end{abstract}

\section{Research Background}

The quality of human resources (HR) is a national asset that is very important for the progress of a country. A country with quality human resources will determine the progress and prosperity of the country itself. Quality human resources can be obtained through education. Education is a planned effort so that students can actively develop their potential so that they have spiritual strength, intelligence, skills, noble character, and character. Therefore, efforts to improve the quality of education must be made to improve the quality of Indonesian human resources who are ready and able to compete with other countries. 
The government as an institution that is responsible for the implementation of education in Indonesia plays a very important role and must be able to carry out and facilitate the implementation of quality education. The government is expected to meet the needs needed by schools so that the learning process in schools can run optimally. Monitoring the quality of education must be carried out periodically and systematically. This was done to find more comprehensive information on the problems faced and to answer questions that often arise in connection with the low quality of education in Indonesia. According to the results of a study conducted by Santoso (2000), the low quality of education is caused by low learning achievement, the difficulty of students in understanding and mastering subject matter, the inability to think critically and to apply the knowledge gained in school in different situations. Teachers as educators have a very big responsibility in developing or improving the competence of students optimally. Teachers who have high material mastery competence are expected to be able to teach all subject matter to students thoroughly and optimally to achieve learning objectives. The success of the teacher in presenting subject matter and the extent to which students have absorbed the subject matter cannot be separated from preparation, mastery of subject matter, and the use of appropriate teaching methods.

The definition of learning outcomes cannot be separated from what happens in learning activities both at school and outside of school. Bloom (1971) states that learning outcomes include three domains: (1) cognitive domain, the focus of this domain is on the ability to think, remember, and solve problems; (2) effective domain, related to values, attitudes, interests, and appreciation; and (3) psychomotor domain, related to motor skills and arranging. Thus it can be said that the learning outcomes can be in the form of a product, such as certain knowledge, attitudes, and skills. The learning experience of students can be influenced by several factors such as the quality of the interaction between students, material, and teachers, as well as the characteristics of students when they get learning. Meanwhile, Bridge, Judd, and Mocck (1979) stated that learning outcomes are a production function of the education system. School quality is a function of an effective learning process, leadership, teacher participation, student participation, management, organization, physical environment and resources, school customer satisfaction, input and facilities support, and school culture. The optimization of each of these components determines the quality of the school as an education delivery unit

Students with special needs who attend formal schools, including human resources, must be facilitated so that these students can attend lessons at school like other students. Schools must be able to facilitate inclusive students. This was reinforced in the 1993 UN resolution on inclusive education and the Minister of Education Regulation Number 70 of 2009 on inclusive education. Herawati (2016) emphasizes that all physical, intellectual, social, emotional, and linguistic disorders, children with disabilities, talents, street children, child laborers, children in remote or migratory communities, children from speaking ethnic groups., ethnic/cultural minorities and 
children vulnerable to marginalization have the right to education without discrimination.

Students with special needs who attend formal schools, especially at the high school level, receive the same subject matter as other students including in the National Examination (UN). The question packages tested in the Exam Nations come from the same lattice so that each student works on an equivalent or parallel exam question package between one student and other students. One of the subjects tested in the High School level Exam Nations is Mathematics. With the limitations of students with special needs, it is necessary to research the ability and absorption of the subject matter.

\subsection{Problem}

The problem raised in this study is how much the ability and absorption of Mathematics subject matter for high school students with special needs in the 2018/2019 academic year.

\subsection{Research purposes}

Based on the formulation of the problem above, the purpose of this study is to obtain information about the ability and absorption of mathematics subject matter for inclusive high school students in the 2018/2019 academic year.

\subsection{Literature review}

Information about the competence of students can be obtained through the measurement process. According to Wiersma and Jurs (1990), measurement is a numerical assessment of the facts to be measured according to certain criteria, while according to Allen \& Yen (1979), measurement is defined as the determination of numbers in a systematic way to express individual circumstances. Thus, the essence of measurement is determining figures about individual facts or circumstances to be measured according to certain rules. In other words, measurement is a broader concept than a test.

One of the measuring tools used to obtain this competency information is a learning achievement test. According to Crocker and Algina (1986), testing is a standard process for obtaining a sample of behavior from a particular domain. Suke Silverius (1991) says that the learning outcome test is a series of questions that must be answered or a task that must be done by students and the results are used to measure student learning progress. Anastasi (1988) states that a learning outcome test or learning achievement test is a test that measures the knowledge a person has due to an educational program or a training program. Cronbach (1960) defines testing as a systematic procedure for observing the behavior of learners and describing them with the help of a numerical or categorical scale.

In daily life at school, teachers still find it difficult to make a good measuring instrument (test). This can be seen from the results of research conducted by 
Kartowagiran and Jaidun (2016) and Setiadi (2016) which state that teachers still do not understand and need guidance in conducting assessments.

According to Umar, et al (1997), the terms of a good test include (1) valid, that is, each measuring instrument only measures one dimension or aspect, and (2) reliability (reliability) of the measuring instrument. Reliability in this case includes the accuracy/accuracy of measurement results. The accuracy of the measurement results is determined by the amount of accurate and reliable information. Meanwhile, The characteristics of the items include the power of difference, the function of the answer choices, and the difficulty level of the items.

According to Suryabrata (1987), the steps that must be taken to obtain a standardized test instrument are: (1) developing test specifications or grids, (2) writing questions, (3) reviewing and revising questions, (4) testing regularly. empirical, and (5) administering the test for standardization purposes. The test instruments used in the UN have gone through a standard or standard process, meaning that the items have been calibrated and are on the same scale so that the scores or scores obtained by students can be compared between provinces, between cities/districts, and between schools.

Hopkins and Antes (1979) stated that the level of problem difficulty was measured by the number of test-takers who answered the questions correctly, and was measured by the number of test-takers who answered incorrectly, while Suryabrata (1987) said that the difficulty level of the items was a proportion. subjects who answered that question correctly. The level of difficulty index is located from 0 to 1 , the greater or closer to one proportion of subjects who answered correctly the easier the question. For example, the difficulty level of the items was 0.87 , meaning that $87 \%$ of the subjects answered correctly and the absorption of the subject matter tested was $87 \%$.

\section{Research Methodology}

This study uses secondary data which consists of three documents, namely: UN grid, question packages, and data on the absorption of the results of the National Examination in Mathematics for the 2018/2019 academic year. Data analysis was performed using quantitative and qualitative techniques. Quantitative analysis is carried out to see the percentage of subject matter mastery and to determine ability (test scores), while qualitative techniques are used to see the characteristics of the grid which includes the scope of the material and the level of ability. The next step is to analyze the data using descriptive statistics. Descriptive statistics are used to describe, present, and inform the research data so that it is easy to read, easy to understand, and more meaningful.

\subsection{Population and Sample}

The population of this study was all students with special needs in Indonesia who took the National Examination for the 2018/2019 academic year, while the research 
sample was all high school students with special needs in inclusive schools who took the National Examination.

\section{Research Results and Discussion}

The number of students with special needs who took the national exams for the 2018/2019 academic year amounted to 422 people, with 13 disabilities. Most of the participants in the inclusion exam were in the Gifted (104 people) and Talented (133 people) categories. Meanwhile, the number of national exam participants for each type of inclusion is presented in Figure 1.

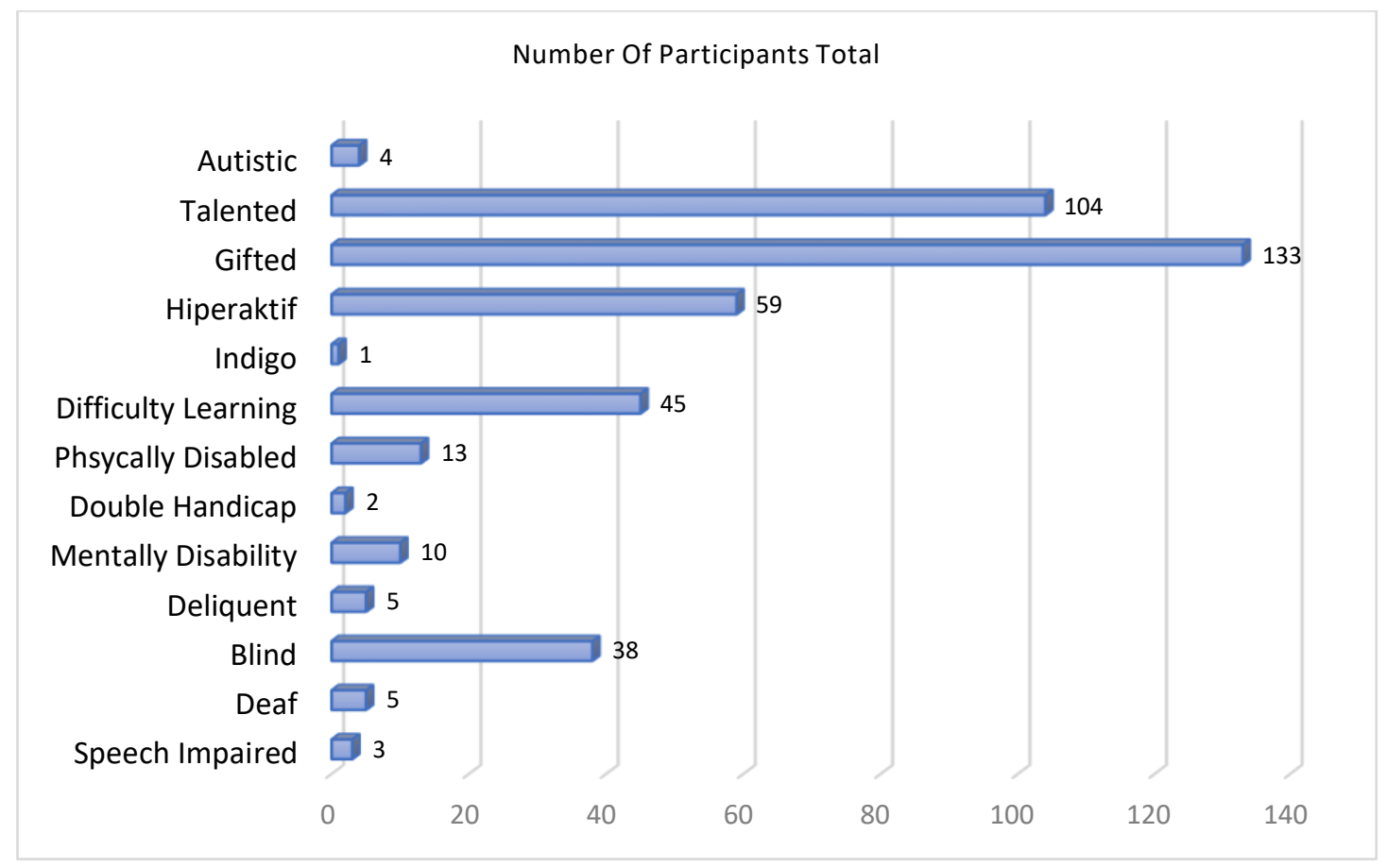

Figur 1. Number Of National Exam Participants with Special Needs.

The ability of inclusive students in mathematics in the 2018/2019 national exam is illustrated through the results of the national exam in the form of a score. The overall score of the national exam scores for students with special needs in Mathematics was 54.59 and the lowest was 22.43 with an average score of 39.43. The average score of the national examination for the inclusion participants in Mathematics for each major (Science, Social Sciences, and Language) at the high school level is shown in Figure 2. 


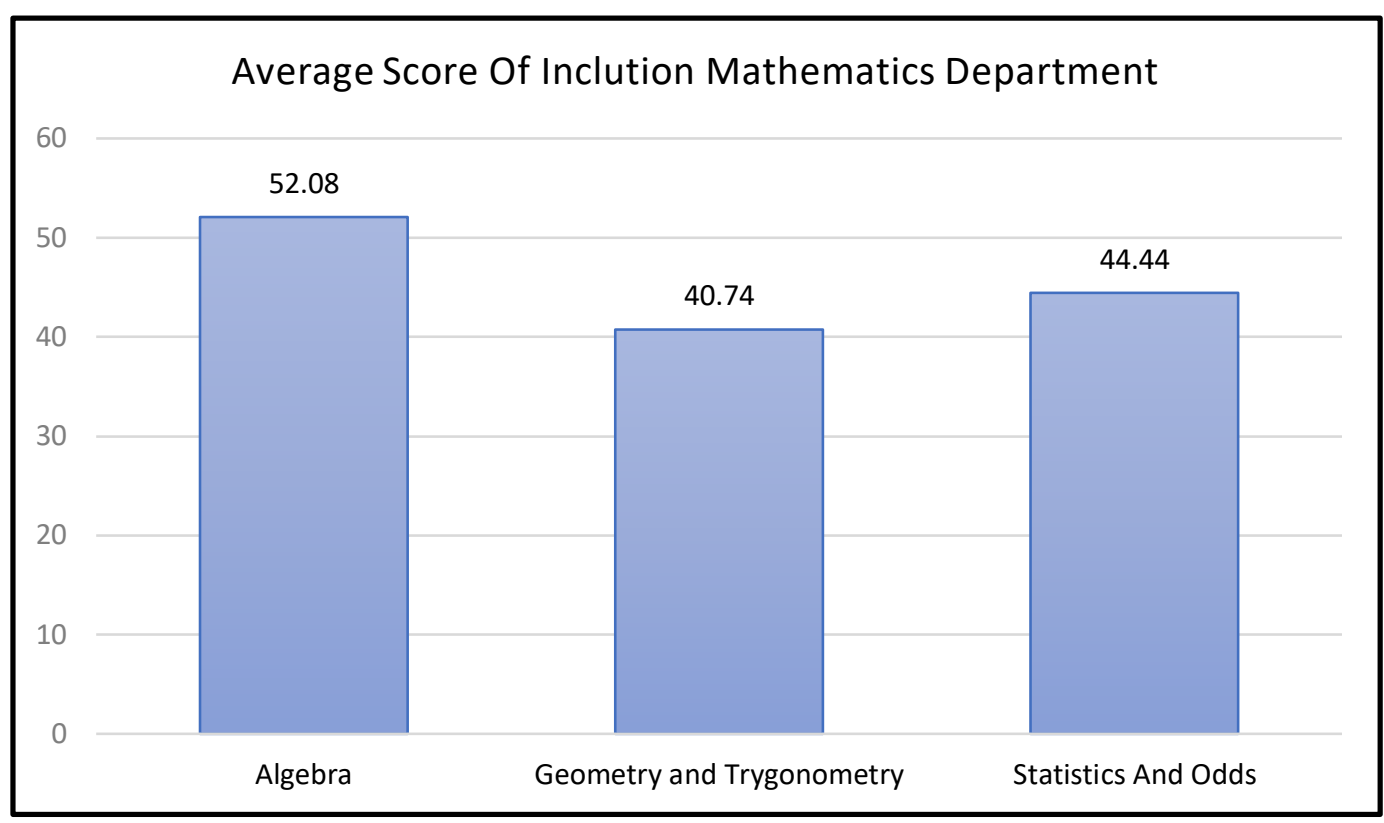

Figure 2. Average Score of Inclusion Mathematics Department

The average score of Mathematics in the Science Department is higher than Social Sciences and Language. Based on the National Examination score classification (Depdikbud, 2012), the average score of Mathematics for Science and Language is in the poor category, while Social Studies is in the very poor category.

The dimensions measured in the national exam consist of a material scope and cognitive level. The scope of the material includes (1) Algebra; (2) Geometry; (3) Trigonometry; (4) Calculus; and (5) Statistics and Odds. The cognitive level is divided into knowledge (know), application (applying), and reasoning (reasoning). The distribution of the percentage of material coverage and cognitive level is presented in Table 1.

Table 1. Distribution of Percentage of Material Scope and Cognitive Level of High School Mathematics Subject in National Examination for the 2018/2019 Academic Year

\begin{tabular}{|l|l|l|l|}
\hline Scope Of Material & Percent & Cognitive Level & Percent \\
\hline Algebra & $50 \%$ & Knowledge & $26 \%$ \\
\hline Calculus & $7.5 \%$ & $\begin{array}{l}\text { Application \& } \\
\text { applying }\end{array}$ & $34 \%$ \\
\hline Geometry And Trigonometry & $17.5 \%$ & Reasoning & $40 \%$ \\
\cline { 1 - 3 } Statistics & $25 \%$ & \multicolumn{2}{|l}{} \\
\cline { 1 - 2 } & \multicolumn{2}{|l}{}
\end{tabular}

In Table 1, it can be seen that the scope of material for Algebra is $50 \%$, higher than the scope of other material. This is related to the breadth of the material. Meanwhile, the cognitive level of reasoning has the highest proportion of the three measured cognitive levels. The distribution of the number of questions for each scope of material and material tested can be seen in Table 2 . 
Table 2. Distribution of the number of questions and materials tested in the National Language Exam Indonesia.

\begin{tabular}{|c|c|c|}
\hline $\begin{array}{l}\text { Scope Of } \\
\text { Material }\end{array}$ & $\begin{array}{l}\text { Number Of } \\
\text { Questions }\end{array}$ & The Material Being Tested \\
\hline Algebra & 20 & $\begin{array}{l}\text { 1. Forms of Power, Root, and Logarithm } \\
\text { 2. Functions, Function Composition, Inverse Functions, } \\
\text { and Function Graphics } \\
\text { 3. Quadratic Equations and Functions } \\
\text { 4. Systems of Equations and Linear Inequality Systems } \\
\text { 5. Linear Program } \\
\text { 6. Matrix } \\
\text { 7. Arithmetic and Geometry Sequences and Series }\end{array}$ \\
\hline $\begin{array}{l}\text { Geometry } \\
\text { and } \\
\text { Trigonometry }\end{array}$ & 6 & $\begin{array}{l}\text { 1. Limit } \\
\text { 2. Derivatives } \\
\text { 3. Integral }\end{array}$ \\
\hline Calculus & 4 & $\begin{array}{l}\text { 1. Comparison of trigonometry } \\
\text { 2. Trigonometric functions and their graphs } \\
\text { 3. Rules of sineses and consines } \\
\text { 4. Position and distance from points, lines and planes } \\
\text { 5. The angle between a line and a plane, and between } \\
\text { two planes } \\
\text { 6. Equations of circles and tangents to circles } \\
\text { 7. Geometry transformations }\end{array}$ \\
\hline Statistics & 10 & $\begin{array}{l}\text { 1. Presentation of data in the form of tables, diagrams } \\
\text { and graph } \\
\text { 2. Size of data center, location, and distribution } \\
\text { 3. Enumeration rules } \\
\text { 4. Event opportunities }\end{array}$ \\
\hline
\end{tabular}

The percentage of students with special needs national exam participants who can correctly answer questions in each scope of material shows their absorption of the material. The absorption capacity of each material scope of the material for the High school, Science, Social, and Language majors is shown in Figure is 4, Figure 5, and Figure 6 respectively. 


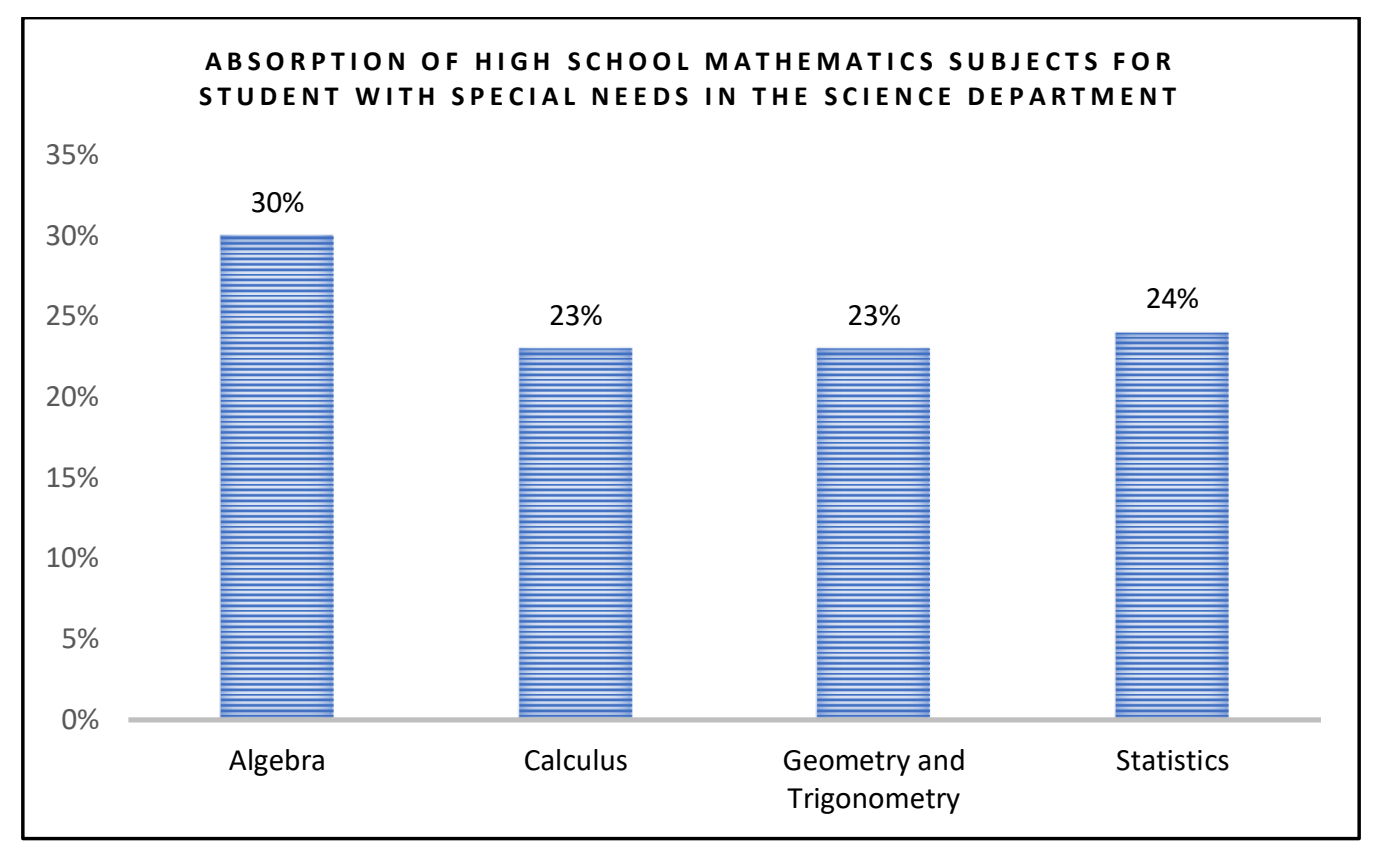

Figure 4. Absorption of High School Mathematics Subjects for students with special needs in the Science Department.

The average absorption power of Mathematics in the Science department is $38 \%$. Figure 4 shows the lowest absorption power in Mathematics for high school students with special needs majoring in science is in the scope of calculus and Geometry \& Trigonometry, $23 \%$. That way, it is necessary to deepen the material related to calculus and Geometry \& Trigonometry. Meanwhile, the highest absorption (30\%) is in the scope of Algebra material.

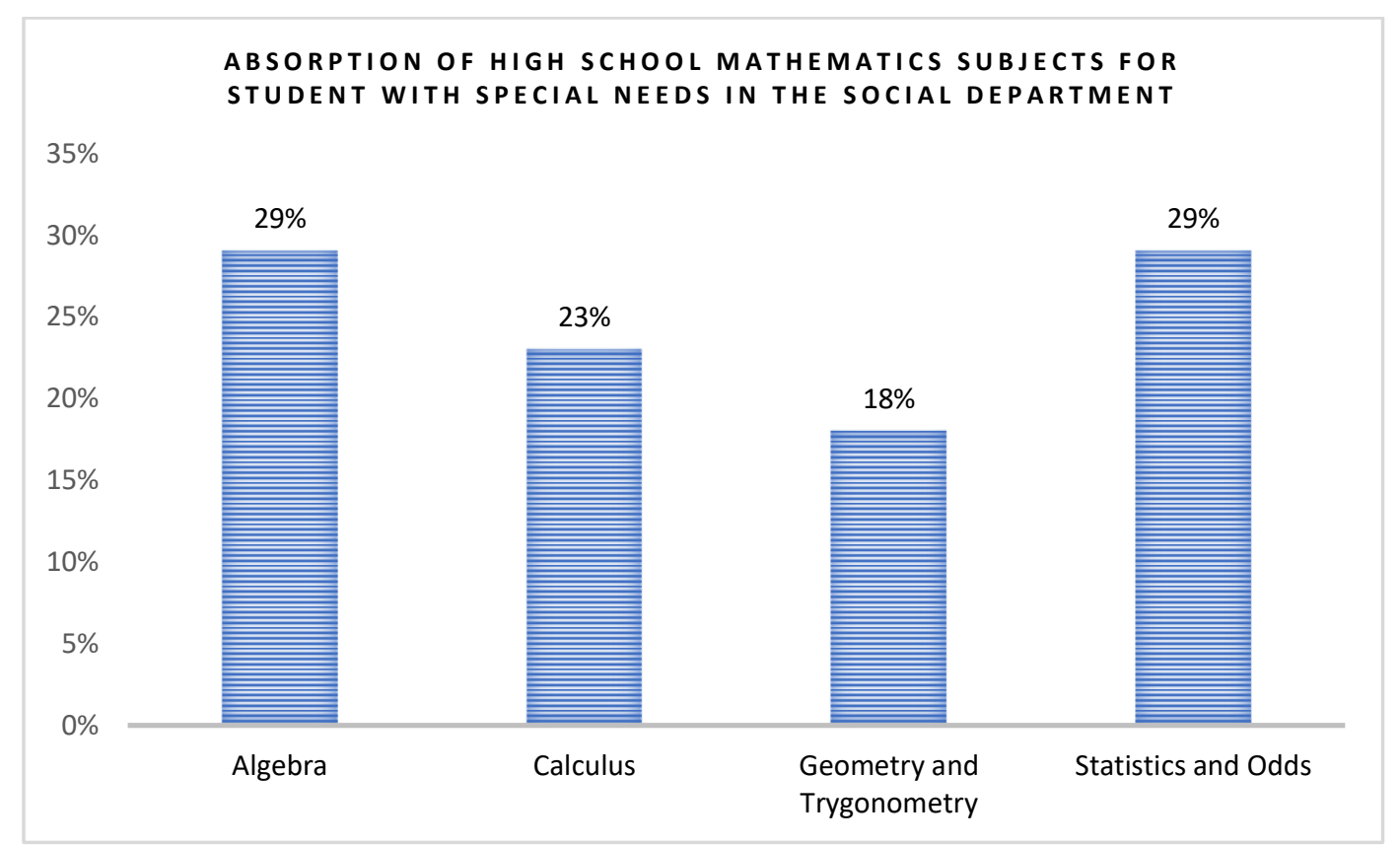

Figure 5. Absorption Of High School Mathematics Subjects For Student With Special Needs In The Social Department

In the Social Studies department, the average absorption power of students with special needs is $26 \%$, the lowest absorption is $18 \%$ in the scope of Geometry and 
Trigonometry, while the highest absorption is $29 \%$ in Algebra and Statistics \& Opportunity. That way, it is necessary to deepen the material scope of the material geometry and trigonometry.

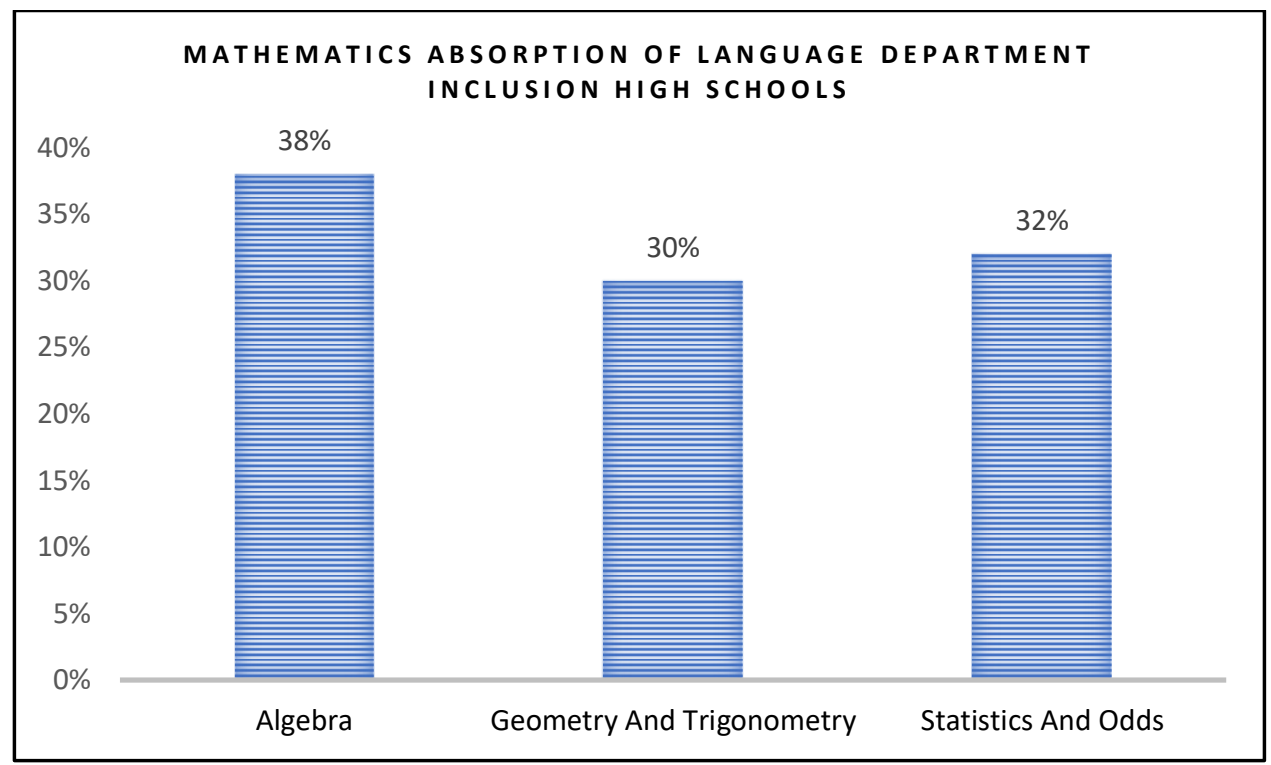

Figure 6 Mathematics Absorption of Language Department Inclusion High Schools

In the Language department, the average absorption power of high school students with special needs is $37 \%$, the lowest is $30 \%$ in the scope of Geometry and Trigonometry material, while the highest absorption is $38 \%$ in the scope of Algebra material.

The skills to solve math problems in each field of study are as follows, (1) Science Department has the highest score in algebra, while the lowest score is calculus and geometry and trigonometry. (2) Social majors have the highest score in Algebra and Statistics and odds, while the lowest score is geometry and trigonometry. (3) finally, the language department has the highest score in algebra, while the lowest score is geometry and trigonometry. When compared to the absorption capacity of the scope of Mathematics subject matter at the average of all Science, Social and Language majors, the lowest absorption is in the scope of Geometry and Trigonometry.

Concrete and functional learning, or by mediating messages that are still functional. These modifications are called special services. According to Mumuniarti (2021), all activities needed in everyday life need the use of mathematics. For this reason, students with special needs also support their daily life. The fields of mathematics include: calculating numbers and their operations, geometric shapes, measurements, and the use of money and time.

\section{Conclusion}

The highest absorption of mathematics subjects was achieved by students with special needs majoring in Science and the lowest in the Department of Social Sciences. The lowest absorption power for the Social Studies and Language majors is Geometry 
and Trigonmetry, and for the Science department is the scope of Calculus material. Special education students in the science, social studies and language majors need to deepen the material. The lowest absorption power of students with needs. In general, it can be said that it is a weakness in Mathematics, namely in Geometry and Trigonometry and also Calculus.

The range of Mathematics values for students with special needs is very large, so they need assistance or guidance so that more of their abilities will increase and be homogeneous. Students with special needs need to deepen the material as a whole, because the national average for mathematics is still lacking, even low.

\section{Bibliography}

Anne Anastasi, (1988). Psychological Testing, $6^{\text {th }}$ ed, New York: Macmillan Publishing Company.

Bloom, Benjamin S, (1971). Taxonomy of Educational Objectives. New York: D Mckay Company Inc.

Bridge, RR.G., Judd, C.M., \& Moock, P.R., (1979). The determinants of educational outcomes, Massachusets: Ballinger Publishing Company.

Badrun Kartowagiran dan Amat Jaidun. (2016). Model Asesmen Autentik untuk Menilai Hasil Belajar Siswa Sekolah Menengah Pertama (SMP): Implementasi Asesmen Autentik di SMP. Jurnal Penelitian dan Evaluasi Pendidikan. Vol 20, No 2, Page 131141 , Yogyakarta.

Crocker, Linda, James Algina, (1986). Introduction To Classical \& Modern Test Theory. Florida: Orlando.

Charles D. Hopkins dan Richard L. Antes. (1979). Classroom Testing Construction. F. E. Peacock: Illionos.

Djaali dan Pudji Mulyono. (2008). Pengukuran dalam Bidang Pendidikan. Jakarta: Grasindo.

Departemen Pendidikan dan Kebudayaan. (2012). Buku Panduan Pemanfaatan Hasil UN,Pusat Pengujian. Jakarta.

Gray L. R., (1996). Educational Research.: Prentice-Hall inc. New Jersey.

Kementerian Pendidikan dan Kebudayaan, (2019). Data Ujian Nasional SMA/MA tahun Pelajaran 2018/2019. Pusat Penilain Pendidikan. Jakarta.

Jahja Umar, et al., (1997). Bahan Penataran Pengujian Pendidikan. Pusat Pengujian Jakarta.

Lee J. Cronbach, (1960). Essential of Psychological Testing, $3^{\text {th }}$ ed, New York: Harper \& Row.

Mary J. Allen, Wendy M. Yen, (1979). Introduction Measurment Theory. California: Montrey.

M. Chabib Thoha, 1996. Teknik Evaluasi Pendidikan. Jakarta: Raja Grafindo Persada.

Mehrens, WA and I. J. Lehman, (1987). Measurment and Evaluation in Educational and Psychology. New York: Holt, Rincchart and Winston, Inc. 
Mumpuniarti. (2011). Pembelajaran Matematika Bagi Siswa Berkebutuhan Khusus JenjangSdlb.Http://Staffnew.Uny.Ac.Id/Upload/131284656/Pendidikan/Modul+Mate matika+Plpg.Pdf. Google: 12 Januari 2020.

Oemar Hamalik, (2003). Perencanaan Pengajaran Berdasarkan Pendekatan Sistem. Jakarta: Bumi Aksara.

Peraturan Menteri Pendidikan Nasional Nomor 75 tahun 2009 Tentang Ujian Nasional Sekolah Menengah Pertama/Madrasah Tsanawiyah, Sekolah Menengah Pertama Luar Biasa (SMPLB), Sekolah Menengah Atas/ Madrasah Aliyah (SMA/MA), Sekolah Menengah Atas Luar Biasa (SMALB), Dan Sekolah Menengah Kejuruan (SMK) tahun Pelajaran 2009/2010. Jakarta.

Peraturan Menteri Pendidikan Nasional Republik Indonesia Nomor 70 Tahun 2009 tentang Pendidikan Inklusif Bagi Peserta Didik Yang Memiliki Kelainan Dan Memiliki Potensi Kecerdasan Dan/Atau Bakat Istimewa https://kelembagaan.ristekdikti.go.id/wp-content/... PDF file

Peraturan Pemerintah Nomor 19 Tahun 2005 tentang Standar Pendidikan Nasional

Puspendik, 2011. Data Survei Nasional Kompetensi Siswa Berdasarkan Hasil UN Rendah. Jakarta.

Resolusi PBB nomor 48/96 tahun 1993 tentang Persamaan Kesempatan bagi Orang Berkelainan the standard rules on the equalization of opportunities for persons with disabilities https://ycaitasikmalaya46111.wordpress.com/2013/01/11/landasanpendidikan-inklusif

Robert Linn, Norman E. Gronlund, (1990). Measurment and Assessment in Teaching, $6^{\text {th }}$ ed. New Jersey: Macmillan Publishing Company.

Saifudin Azwar (1987). Tes Prestasi Fungsi dan Pengembangan Pengukuran Prestasi Belajar, Yogyakarta: Liberty.

Sallis, E., (2002). Total quality management in education, London: Kogan Page Limited.

Setiadi, Hari, (2016). Pelaksanaan Penilaian pada Kurikulum 2013. Jurnal Penelitian dan Evaluasi Pendidikan, Vol 20, No 2, Page 131-141.

Santoso, Guritaningsih, et all., (2000). Studi Perkembangan Kognitif Siswa SD. Jakarta: Lembaga Penelitian Universitas Indonesia.

Silverius, Suke. (1991). Evaluasi Hasil Belajar dan Umpan Balik. Jakarta: Gramedia.

Suharsimi Arikunto, (1997). Dasar-dasar Evaluasi Pendidikan, Jakarta: Bumi Aksara.

Sumadi Suryabrata, (1987). Pengembangan Tes Hasil Belajar, Jakarta: Rajawali.

Suyanto, 2012. Power point Pengembangan dan Pembinaan Guru Sekolah Dasar Berkarakter. Jakarta: Kementerian Pendidikan Nasional.

Toto Subroto. (2018). Analisis Hambatan Belajar Pada Materi Trigonometri Dalam Kemampuan Pemahaman Matematis Siswa. https://www.researchgate.net/publication/327958836_Analisis_Hambatan_Belaja r_Pada_Materi_Trigonometri_Dalam_Kemampuan_Pemahaman_Matematis_Sisw a. Google: 13 Januari 2021.

Umar, Jahja, Bahrul Hayat, (2000). Efektifitas Pengujian Soal Bentuk Soal Pilihan Ganda dan Benar Salah. Jakarta: Pusat Pengujian. 
84 | Indonesian Journal of Disability Studies

Wiersma, William and Stephen G. Jurs, (1990). Educational Measurment and Testing, $2^{\text {th }}$ ed, Boston: Allyn and Bacon.

Zakaria, Ramli T., Deni Hadiana, (2006). Ujian Nasional. Jakarta: Pusat Penilaian Pendidikan. 